BOTANICA

ISSN 2538-8657

2020, 26(2): 170-183

\title{
NEW ALIEN PLANT SPECIES RECORDED IN SOUTH LITHUANIA
}

\section{Zigmantas GUDŽINSKAS*, Laurynas TAURA}

Nature Research Centre, Institute of Botany, Žaliųų Ežerų Str. 49, 12200 Vilnius, Lithuania

*Corresponding author. E-mail: zigmantas.gudzinskas@gamtc.lt

\begin{abstract}
Gudžinskas Z., Taura L., 2020: New alien plant species recorded in South Lithuania. - Botanica, 26(2): 170183.

Performing a thorough inventory of alien plant species in the southern part of Lithuania, we found twelve alien plant species previously not registered in the country: Aruncus dioicus, Buxus sempervirens, Clematis vitalba, Clematis recta, Colutea arborescens, Erechtites hieraciifolius, Erigeron strigosus, Euphorbia marginata, Genista sagittalis, Lathyrus latifolius, Sempervivum arachnoideum and Silphium perfoliatum. All newly recorded alien species, except Erechtites hieraciifolius and possibly Genista sagittalis, have been introduced intentionally and escaped from cultivation. Ten species currently occur as casuals, whereas Colutea arborescens and Genista sagittalis are locally naturalised. Naturalisation of Buxus sempervirens and Euphorbia marginata in the foreseen future is unlikely in Lithuania, naturalisation of Aruncus dioicus, Sempervivum arachnoideum and Silphium perfoliatum is possible. In contrast, naturalisation of the other five species is expected in the nearest future. Invasion of seven analysed alien species is unlikely in Lithuania, whereas Clematis vitalba, Colutea arborescens, Erechtites hieraciifolius, Erigeron strigosus, Lathyrus latifolius have the potential to become invasive in the country. Therefore, their reproduction and spread should be monitored, and measures for prevention of their invasion should be applied, if necessary.
\end{abstract}

Keywords: alien species, casual species, invasiveness, naturalisation, reproduction.

\section{INTRODUCTION}

The invasion of alien plant species is an essential component of global environmental change, and the process has accelerated significantly throughout the world during several last decades (Hulme, 2003; Keller et al., 2011; Seebens et al., 2015). A constant increase in the number of alien plant species virtually in all regions of the Earth is responsible for the homogenisation of floras (Hulme, 2003; KüHN \& KLOTZ, 2006).

Prevention of the spread of potentially invasive plant species is possible with relevant information on newly arrived alien species (Hulme et al., 2018; REASER et al., 2020). Early detection is the best way to deal with invasive alien species because it gives the ability to monitor and track their spread at the initial stages of introduction and undertake appropri- ate management decisions, if necessary (MAXwELL et al., 2009). Therefore, constant investigations on the diversity, spread and naturalisation of alien species are crucial, aiming to prevent or minimise new invasions (Hulme et al., 2018; ReAser et al., 2020).

There are numerous pathways of alien plant species introduction, however, nowadays escaping of intentionally introduced plant species from horticulture, silviculture and various plantations has been recognised as the main introduction pathway (PERGL et al., 2016; van Kleunen et al., 2018; Hulme et al., 2018; Guo et al., 2019). The role of unintentional introductions has significantly decreased during the last decades (Pergl et al., 2016; Hulme et al., 2018). Although only a small fraction of alien plant species have become naturalised and even less of them invasive (PYŠEK \& RichARDSON, 2006), constant monitoring of both, long ago established and newly arrived 
species is a particularly important task, as a significant lag period between species introduction and its spread is a well-known phenomenon (KowARIK, 1995; LARKIN, 2012). The effect of environmental disturbances coped with climate change may set in motion and facilitate many future invasions (THEOHARIDES \& Dukes, 2007; Haeuser et al., 2018; Shrestha \& Shrestha, 2019).

Several dozens of alien plants species new to Lithuania have been recorded during the last decade (GuDŽINSKAS et al., 2014, 2017, 2019; GUDŽINSKAS \& Petrulaitis, 2014; Petrulaitis \& Gudžinskas, 2020). In 2020, implementing the project "Investigations of the Status of Invasive and Alien Species in Lithuania”, we performed thorough studies of alien plant species in South Lithuania. We found 12 previously not recorded alien plant species. This study aimed to report newly found alien species in Lithuania, to present data on their distribution, abundance, and considerations on the level of their naturalisation in the country.

\section{MATERIALS AND METHODS}

Alien plant species reported in this paper were first registered in Lithuania mainly during growth season of 2020; however, records of two new alien species, made in 2016 and 2019 in South Lithuania, were also included. Most records of the reported new alien species were made implementing the project "Investigations of the Status of Invasive and Alien Species in Lithuania" (see Acknowledgements) in South Lithuania, in Alytus, Druskininkai, Kalvarija, Lazdijai, Marijampolè, Šalčininkai and Varèna districts. During the investigation, the total area was systematically observed by visiting various types of both anthropogenic and natural habitats, significant attention paying to areas with potentially highest diversity of alien species (abandoned lands, banks of rivers, edges of forests, environs of settlements, roadsides, etc.). The records in Trakai district were made implementing other research projects. Herbarium specimens of the reported plant species were deposited at the Herbarium of the Institute of Botany of the Nature Research Centre (BILAS) in Vilnius. The list of examined herbarium specimens is provided in Appendix I.

Alien plant species in the text were arranged in alphabetical order. Plant families were provided under an updated Angiosperm Phylogeny Group classification for the orders and families of flowering plants (APG, 2016). Geographical co-ordinates were indicated according to WGS 1984 standard.

\section{RESULTS AND DISCUSSION}

Twelve alien plant species previously not registered in Lithuania were recorded performing a thorough inventory of alien plant species in the southern part of the country. Among the newly recorded alien plants, five species of perennial herbs, three species of woody plants (shrubs and subshrubs), two species of annual herbs, one species of biennial herbs, and one species of woody vines. Below we present main characteristics of the new species, information on their native and alien ranges, revealed localities and considerations about the possibilities of naturalisation of each species and further spread in Lithuania.

Aruncus dioicus (Walter) Fernald, Rosaceae, is a robust, perennial, clump-forming herb native to the temperate regions of Europe, Asia, and North America. In the native range, this species prefers dump and shady habitats, mainly in mountain regions (Tutin, 1968a; KuRTTO et al., 2004). It is a widely cultivated ornamental plant and as a naturalised alien occurs in the British Isles, Scandinavia, Finland, Estonia, and Russia (Stace, 1997; Kurtto et al., 2004; GederAAS et al., 2012). The northern border of the native range of A. dioicus in Europe stretches just south of Lithuania in eastern Poland and western Belarus. In contrast, in Kaliningrad Region of Russia, it occurs as naturalised alien (KURTTO et al., 2004).

We found the first locality of escaped $A$. dioicus in Varena district, in the environs of Papiškiai village, at Lake Savistas. A group of eight clumps was found growing at the edge of the black alder (Alnus glutinosa (L.) Gaertn.) stand. This species was also found in Margionys village at the edge of the pine forest near the cemetery and in the environs of Samūniške village, in native pine plantation (Varèna district). In both localities solitary clumps occupying $1 \mathrm{~m}^{2}$ and $2 \mathrm{~m}^{2}$, respectively, were recorded. One locality of this species was found in the environs of Mizarai village (Druskininkai district), at the edge of the black alder stand by the Bilsinyčia Rivulet, where a large and dense clump, occupying ca. $6 \mathrm{~m}^{2}$, was found. 
We suppose that in all localities, except Papiškiai, the source of $A$. dioicus introduction were roots discarded with garden wastes. In Papiškiai, several individuals along the edge of the black alder stand probably grew from seeds brought with garden wastes. Male and female individuals (five and three plants, respectively) were found at the site. Currently, we consider A. dioicus as a casual species in Lithuania. Its naturalisation in the country is expected, but its invasion in the nearest future is unlikely.

Buxus sempervirens L., Buxaceae, is an evergreen shrub or small tree, native to the sub-Mediterranean region of southern Europe, North Africa, and West Asia (Webi, 1968; Decocq et al., 2004). In the native range, it usually grows as understorey shrub in old forests and the open dry montane scrub (DECOCQ et al., 2004). B. sempervirens is widely cultivated as an ornamental shrub and is considered as an archaeophyte, naturalised or casual alien in other regions of Europe (KarlsSon, 1998; Essl \& RaBITSCH, 2002; DeCOCQ et al., 2004; GederaAs et al., 2012) and Asia (KHuRoo et al., 2007).

In Lithuania, B. sempervirens was first recorded in Varèna district, $4 \mathrm{~km}$ south of Vydeniai, in Dainava village. Two much branched shrubs of $1 \mathrm{~m}$ and $1.3 \mathrm{~m}$ tall were found in a dry abandoned grassland at the edge of the forest in the vicinity of the cemetery. Considering the size of shrubs, we suppose that they grow here for at least a decade. Individuals were probably thrown from the cemetery and took root or grew from discarded and rooted branches. Currently, $B$. sempervirens occurs in Lithuania as a casual alien, and its naturalisation is unlikely in the foreseen future.

Clematis recta L., Ranunculaceae, is a perennial plant with erect or ascending herbaceous stems, native to West, South, Central and East Europe, and West Asia (AKeroyd, 1993). In the native range, it usually grows on the margins of woodland areas, in dry grasslands and on slopes, usually in well-illuminated areas (OBERDORFER, 1983; AKEROYd, 1993). As an alien, this species has been recorded in Estonia (KukK, 1999), Norway (GederaAs et al., 2012) and Sweden (Karlsson, 1998). Although in Poland, this species is native (KAŹMIERCZAKOwA et al., 2016), several anthropogenic localities have been registered in the north-eastern part of the country (FyAŁKOWSKA \& AdAMOWSKI, 2017).

In Lithuania, C. recta was first recorded in Lazdijai district, $4.5 \mathrm{~km}$ north of Veisiejai, at the edge of the pine forest, in 2016. Single clump with multiple abundantly flowering stems (ca. 20) was found in dry grassland formed on slopes of an old sand-pit. In the same year, this species was also recorded in Trakai district, in Užutrakis Manor Park, on a dry slope, under the canopy of trees. Two individuals with solitary stems were found, but only one of them had small inflorescence. We suppose that in the first locality, C. recta had been introduced with garden wastes. In contrast, in the second locality, it could be a relic of former cultivation. Currently, this species is a casual alien in Lithuania, but its local naturalisation is possible.

Clematis vitalba L., Ranunculaceae, is a deciduous vine, native to temperate regions of Europe, North Africa and West Asia (Akeroyd, 1993). It has been cultivated for a long time as an ornamental plant and occurs as an alien species in many European countries. As a naturalised and invasive or potentially invasive species, it is recognised in Poland (TokArska-GuziK et al., 2012), Norway (GedERAAS et al., 2012), Ireland (REYNOLDS, 2000). It is also recorded in Denmark, Sweden (Karlsson, 1998) and Estonia (KUKK, 1999); however, the level of naturalisation in these countries is not specified. Clematis vitalba is also recognised as an invasive species in several other regions of the world (BUNGARD et al., 1997).

Clematis vitalba was first recorded in Trakai district, Lithuania, on the outskirts of Lentvaris city, in the grey alder stand on the slope of the Rivulet Saide. The thicket of C. vitalba occupied ca. $80 \mathrm{~m}^{2}$ area and stems reaching up to $7 \mathrm{~m}$ height in the canopy of trees. Stems of the largest individuals were from $32 \mathrm{~mm}$ to $41 \mathrm{~mm}$ in diameter at $0.5 \mathrm{~m}$ from the ground level. Thus, we suppose that $C$. vitalba has been growing here for at least ten years. Currently, this species in Lithuania should be treated as a casual alien, however, considering its quite wide distribution in Poland (TOKARSKA-GuZIK et al., 2012) and Kaliningrad Region of Russia, its naturalisation in Lithuania is expected. This species should be monitored because it has the potential for an invasion in the future. 
Colutea arborescens L., Fabaceae, is a deciduous, 1-4 m tall, much-branched shrub (Fig. 1), native to West, South and Central Europe, North Africa and West Asia. It is frequently cultivated as an ornamental and for erosion control (BRowicz, 1968). This species is a naturalised alien in the Czech Republic (PYŠEK et al., 2012) and the British Isles (Stace, 1997), whereas in Denmark and Sweden it is considered as a casual alien (HARTVIG et al., 1992; JonSELL, 2010). Colutea arborescens has been reported as a rare ornamental plant in Lithuania (NAVASAITIS, 2008) and Latvia (LAIVIṆš et al., 2009).

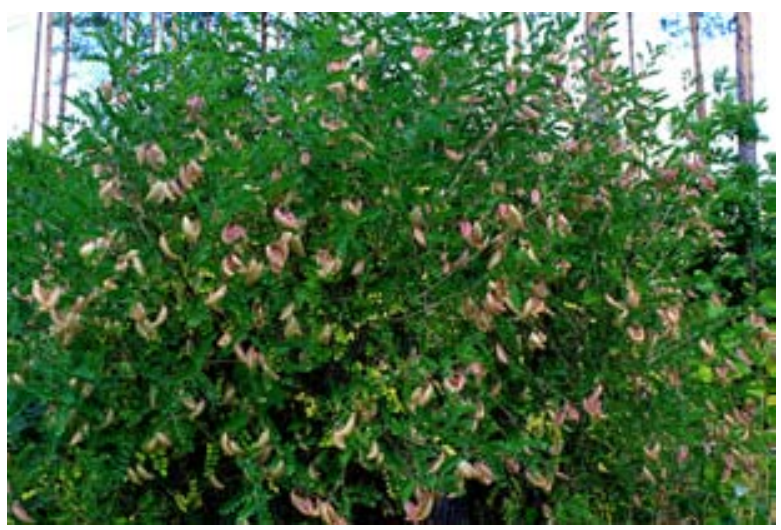

Fig. 1. Colutea arborescens with abundant fruits growing in a sparse pine woodland, July 2020. Photo by Z. Gudžinskas

We recorded the first locality of C. arborescens in Alytus district, $2 \mathrm{~km}$ east of Ryliškiai, in the environs of Taručionys village. A large and dense population of this species occupied quite a large area of the sparse mature pine woodland. Individuals of various heights ranging from $0.7 \mathrm{~m}$ to $4 \mathrm{~m}$, with abundant fruits were recorded at the site. We suppose that this species was introduced in the forest several decades ago, became naturalised and started to spread to surrounding areas. Considering the size of the population and the density of individuals, we conclude that C. arborescens has naturalised at this site. It is essential to conduct comprehensive studies on the population structure, reproduction and spread strategies, and to assess the invasive potential of the species.

Erechtites hieraciifolius (L.) Raf. ex DC., Asteraceae, is an annual, usually much-branched herb, $0.5-2.0 \mathrm{~m}$ tall, occasionally taller (Fig. 2). This species is native to North and Central America, where it grows in forest clearings, shores of lakes, various wetland areas (BARKLEY, 2006; DARBYShiRe et al., 2012). As an alien species, it has spread in Europe (GóRsKi et al., 2003; PYšEK et al., 2012; ZANIEWSKI et al., 2020) and Asia (Mito \& Uesugi, 2004; DarBYSHIRE et al., 2012). The fast spread of this species during the last decade has been noted in East Europe (Tretjakov et al., 2011; Celka et al., 2017; KolomiYCHUK et al., 2019; ZANIEWSKI et al., 2020).

The first locality of E. hieraciifolius in Lithuania was recorded in Varena district, in the environs of Margionys village, in the Margionys Forest. Two groups of individuals separated by ca. $100 \mathrm{~m}$ were found. The first group consisting of ca. 20 plants was found in the pine forest, on the former timber storage area. The second dense group consisting of ca. 200 individuals on $1.5 \mathrm{~m}^{2}$ patch was recorded in the mature pine forest. Several individuals in the middle of August were with ripe and already shed fruits. Therefore, the further spread of E. hieraciifolius is expected. Introduction pathways are not entirely clear, but it might have been introduced with timber processing machinery or by natural means, probably seeds have been brought by the wind. Currently, this species should be treated as a casual alien; however, considering the distribution of E. hieraciifolius in the neighbour regions, there is a remarkably high probability of its naturalisation and invasion in Lithuania.

Although the International Code of Nomenclature (TuRLAND et al., 2018) clearly defines the gender of the generic names with the ending -ites as masculine (Art. 62.4), the spelling of the name of E. hieraciifolius still often varies in the literature. Some authors treat the generic name as feminine (CELKA et al., 2017; ToKARyUK et al., 2017; KolomiychuK et al., 2019; ZANIEWSKI et al., 2020, etc.).

Erigeron strigosus Muhl. ex Willd., Asteraceae, annual, biennial or short-lived perennial herb native to North America. In the native range, it grows along woodland edges, in fields, along roadsides and other open, disturbed sites (NESOM, 2006). Although E. strigosus is usually included into the lists of species of Europe (WaGENITZ, 1965; HaLliday, 1976), its existence in the continent is disputed. Much confusion to the knowledge of the taxonomically challenging Erigeron sect. Phalacroloma (Cass.) Torr. and A. Gray added different circumscription of its two 


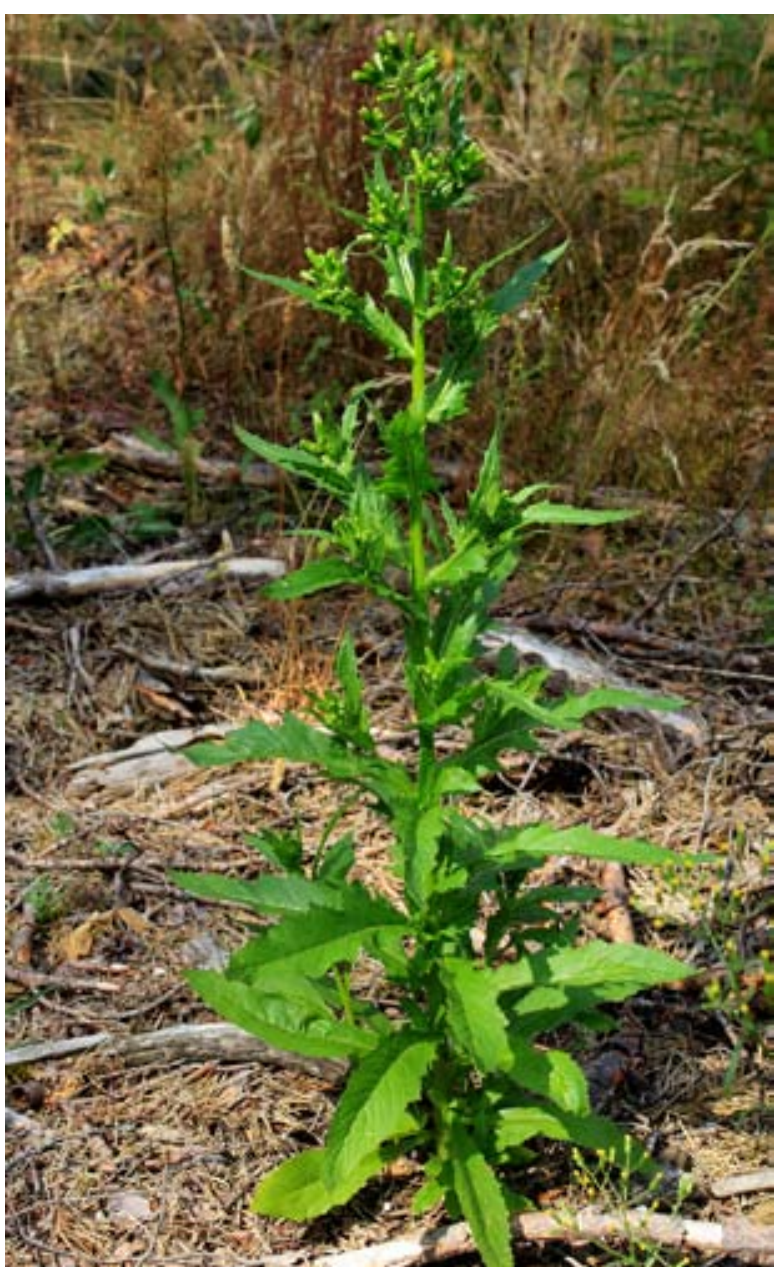

Fig. 2. Flowering Erechtites hieraciifolius in the environs of Margionys, Varèna district, on the former timber storage area in the pine forest, August 2020. Photo by Z. Gudžinskas

species, E. annuus (L.) Desf. and E. strigosus, the inclusion or exclusion of infraspecific taxa (WAGENitz, 1965; Nesom, 2006; Sennikov \& Kurtto, 2019). Basing on the results of cytological studies, FREY et al. (2003) have concluded that there is no proof that E. strigosus occurs in Europe. However, recent studies have confirmed the occurrence of this species in Finland, the Czech Republic, the Netherlands, Austria, Italy, Poland, Russia (Sennikov \& Kurtto, 2019) and Germany (Otto \& Verloove, 2019).

We found the first locality of E. strigosus in Lazdijai district, $4 \mathrm{~km}$ northwest of Veisiejai, in the Liūnelis Strict Nature Reserve of Veisiejai Regional Park in 2019 (Fig. 3). A small group, consisting of about a dozen flowering individuals and few unflowering rosettes, occurred in dry grassland, around

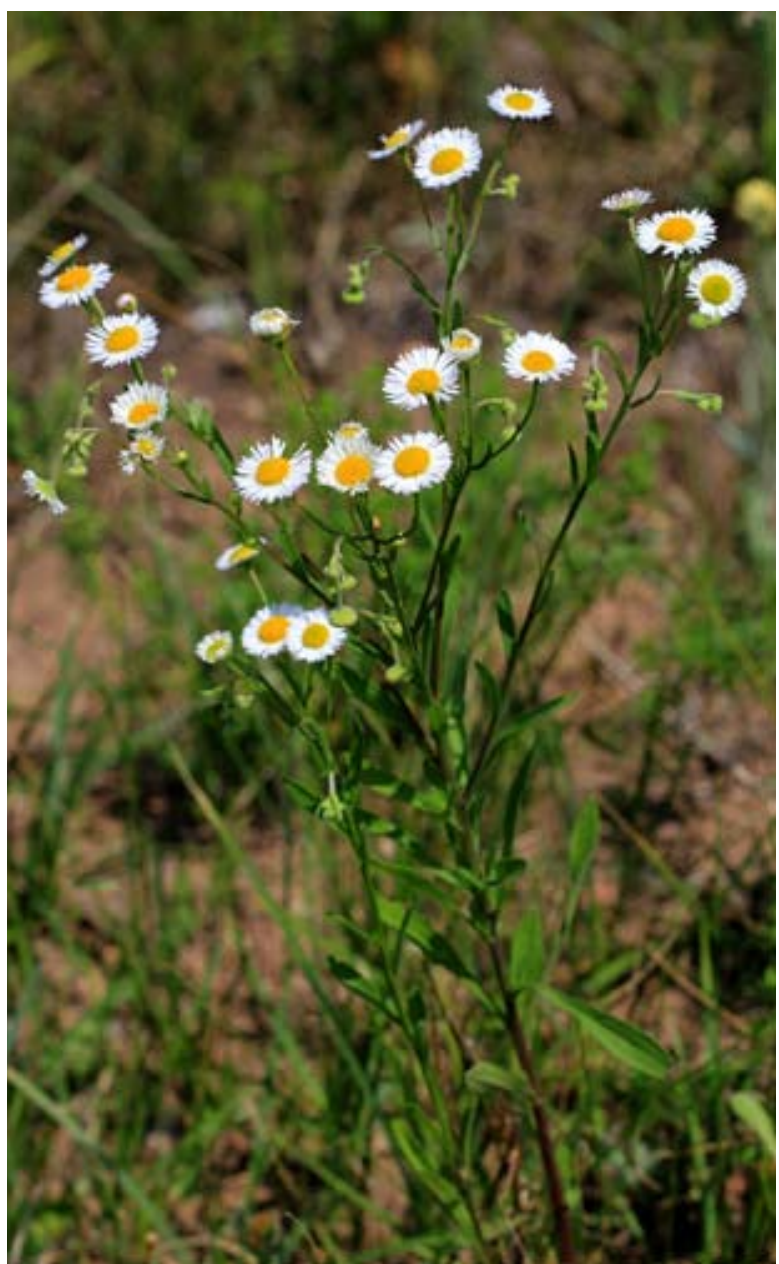

Fig. 3. Flowering Erigeron strigosus in the Liūnelis Strict Nature Reserve, July 2019. Photo by Z. Gudžinskas

aboveground ant nests and mole holes. Means of the introduction of this species into the locality are uncertain; however, it was probably accidentally introduced by humans or seeds brought by the wind. Considering the quite wide distribution of this species in Europe (Sennikov \& Kurtto, 2019; Отto \& VerLOOVE, 2019), we suppose that it could be much wider distributed in Lithuania and further studies are needed.

In August of 2020, we revisited the locality and found almost the same number of flowering individuals as it was in 2019 and more than 20 individuals at the rosette stage. E. strigosus reproduces by seeds at the site. However, currently, we treat this species as a casual alien in Lithuania, but its naturalisation and invasion, like E. annuus, is expected. 
Euphorbia marginata Pursh, Euphorbiaceae, annual, usually much-branched herb with showy, white-margined distal leaves, native to the central United States. In the native range, it occurs in dry grassland and various disturbed areas (BERRY et al., 2016). This species is widely cultivated as an ornamental plant in Europe and other continents (CARTER \& Cullen, 1997; Berry et al., 2016). Euphorbia marginata has been reported as casual alien species in Austria, the Czech Republic, Germany, Greece, Hungary, Italy, Poland, Slovakia and most of the countries in the Balkan Peninsula (EssL \& RABITSCH, 2002; Arianoutsou et al., 2010; MedveckÁ et al., 2012; Woch, 2012; MASLO \& ŠArić, 2018; AyMERICH \& SÁEZ, 2019). Currently, E. marginata is considered as naturalised and invasive species in the Iberian Peninsula (AYMERICH \& SÁEZ, 2019).

In 2020, we recorded E. marginata in two localities in South Lithuania. The first locality was in Alytus district, in Muiželenai village, at the roadside. Two individuals were recorded on the disturbed soil between the road and the shrub stand. The second locality was revealed in Šalčininkai district, in Dainava village, at the roadside. Six individuals with ripe fruits were recorded on the disturbed soil in this locality. Seeds of E. marginata were accidentally brought to the roadsides probably by humans managing garden plant wastes or soil. E. marginata is currently a casual alien species in Lithuania, and its naturalisation at least in the nearest future is not expected.

Genista sagittalis L., Fabaceae (Chamaespartium sagittale (L.) P.E. Gibbs; Genistella sagittalis (L.) Gams), is procumbent, suffruticose, rhizomatous plant, with leaf-like stems (Fig. 4). This species is native to West and South Europe (Tutin, 1968b; TALAVERA, 1999). Solitary easternmost native localities of this species have been recorded in the north-western part of Turkey (EFE et al., 2009). In the native range, it occupies dry grasslands, open mixed and conifer forests, hillsides and mountain slopes (TALAVERA, 1999). Genista sagittalis is a rare naturalised species in the Czech Republic (DANiHelKa et al., 2012; PYšEK et al., 2012) and Poland (ToKarsKa-GuZIK et al., 2012). In Poland, it occurs mainly in the southern part of the country (ZAJĄC \& ZAJAC, 2001) where it grows along forest edges, in dry grasslands, usually in dry and infertile sandy soils (TOKARSKA-GUZIK et al., 2012).

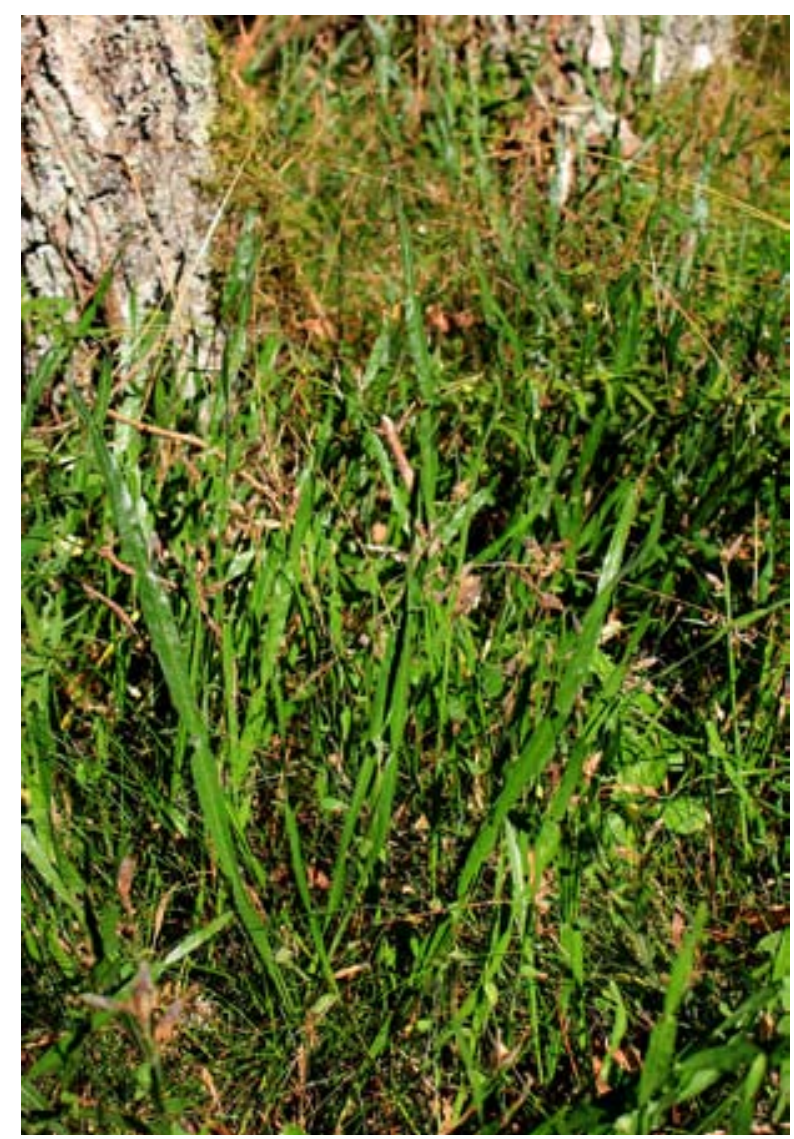

Fig. 4. Genista sagittalis in the pine forest in the environs of Merkinè, August 2020. Photo by Z. Gudžinskas

The first locality of G. sagittalis in Lithuania was revealed in Varena district, about $3.5 \mathrm{~km}$ north-east of Merkine, in the Laporaisčiai Forest, in the woodland developed on the sandy soil and dominated by mature Pinus sylvestris L. Tree layer in the habitat was quite sparse, it covered $40 \%$. Shrub layer (covered 30\%) was dominated by Juniperus communis L. and Betula pendula Roth. Herb layer was quite dense (covered 50\%), dominated by Deschampsia flexuosa L., Melampyrum pratense L., Vaccinium myrtillus L. and $V$. vitis-idaea L. Bryophyte layer was dense (covered $70 \%$ ) and dominated by Hylocomium splendens (Hedw.) Schimp., Pleurozium schreberi (Willd. ex Brid.) Mitt. and Ptilium crista-castrensis (Hedw.) De Not.

Four large patches, occupying from $20 \mathrm{~m}^{2}$ to $60 \mathrm{~m}^{2}$ and several small patches, ranging from less than $1 \mathrm{~m}^{2}$ to $2 \mathrm{~m}^{2}$, were found in this locality. The total area occupied by colonies of Genista sagittalis, with its coverage ranging from 70 to $90 \%$, comprises 
ca. $180 \mathrm{~m}^{2}$. Generative shoots in all surveyed patches in the mid-August of 2020 were with ripe pods, and half of them were already opened. Thus, G. sagittalis produce normally developed seeds in Lithuania, and we suppose that plants forming small patches in a significant distance from large patches are relatively young individuals grown from seeds.

Considering the size of patches formed probably by vegetative reproduction, we suppose that $G$. sagittalis was introduced to the locality at least three or four decades ago, presumably with seeds of Cytisus scoparius (L.) Link. In the second half of the 20th century, C. scoparius was widely sown in pine forests to increase soil fertility and as a fodder plant for game animals (TAura \& GudžInsKas, 2020). Thus, seeds of Genista sagittalis might have been sawn as an accidental or intentional admixture to the seeds of Cytisus scoparius. Currently, Genista sagittalis should be considered as a naturalised alien species in Lithuania.

Lathyrus latifolius L., Fabaceae, is a perennial climbing herb, native to the West and South Europe, southern parts of Central and East Europe. It is also frequently cultivated as an ornamental or fodder plant (BALL, 1968). L. latifolius is naturalised in Sweden (KARLSSON, 1998), whereas in Norway, it is considered as invasive with a potentially high negative impact on ecosystems (GEDERAAs et al., 2012). As casual alien species, it has been recently recorded in Latvia (NĀBurga \& Evarts-Bunders, 2019). L. latifolius was introduced in Lithuania in the first half of the 20th century, and NATKEVIČAITE (1951) has predicted that it has the potential to escape from cultivation. However, escaped plants first were recorded in 2020 only.

We found the first locality of escaped L. latifolius in Alytus district, in the environs of Daugai, in Sala village, at the edge of the shrub stand by the road. Other three localities were recorded in Varena district: in Merkinè and Dargužiai settlements and the vicinity of Liškiava village. In Dargužiai, a small group of plants was found at the edge of the shrub stand by the road; in the environs of Liškiava L. latifolius occupied ca. $2 \mathrm{~m}^{2}$ in abandoned dry grassland. The largest population of this species was recorded in Merkinè, where it occupied ca. $46 \mathrm{~m}^{2}$ area in a dry grassland on a slope and this species covered about
$30 \%$ of the surface. We suppose that this species in all localities occurs as escaped from cultivation. Its seeds probably have been introduced with discarded garden wastes. Currently, L. latifolius should be considered as a casual alien species; however, its naturalisation and further spread are expected. Further studies on the distribution of this species as well as potential invasiveness in Lithuania are required.

Sempervivum arachnoideum L., Crassulaceae, is a rosette-forming succulent perennial plant native to Europe, occurring mainly in the Alps, Apennines and Pyrenees (JALAS et al., 1999). It is frequently cultivated as an ornamental plant in other regions of Europe (KneEs et al., 1995; PetŘíK et al., 2019). This species has been only occasionally reported escaped from cultivation with limited distribution outside its native range in Europe (JALAS et al., 1999; MATTHEWS et al., 2014).

The first locality of escaped $S$. arachnoideum in Lithuania was recorded in Lazdijai district, in Šventežeris village, on a dry sandy, the slightly eroded slope at the cemetery, where it formed a dense patch occupying ca. $2 \mathrm{~m}^{2}$. Although the patch consisted of more than 200 individual rosettes, only a small fraction of them (12 individuals) were in the generative stage. Considering a dense and compact patch of this species, we suppose it has formed from one or few individuals by vegetative reproduction over several years. Currently, S. arachnoideum should be considered as a casual alien in Lithuania. New records of escaped S. arachnoideum in other areas of the country are expected, because it is frequently cultivated species, particularly in cemeteries. The naturalisation of this species, at least locally, is possible in Lithuania, but its invasion in the foreseen future is unlikely.

Silphium perfoliatum L., Asteraceae, is a tall perennial herb, native to the eastern part of North America. In the native range, it occurs in wet prairies, open forests and along rivers (BARKLEY, 1986). This species is quite widely cultivated as an ornamental and a fodder plant. Silphium perfoliatum is naturalised in France, Switzerland, Italy, Germany and Ukraine, where it spreads along roads, on riverbanks and in damp meadows (TuTIN, 1976; GreuTER, 2006; PASHKEVICH, 2020). In other countries of 
Central, North and South-East Europe, it is recognised as a casual alien (GREUTER, 2006; GEDERAAs et al., 2012; PYŠEK et al., 2012; MolnÁR et al., 2019).

In Lithuania, $S$. perfoliatum was first found in Varena district, in the environs of Liškiava village. The stand of this species occupying ca. $3 \mathrm{~m}^{2}$ occurred in pith, at the edge of the forest. We suppose that propagules (possibly roots) of $S$. perfoliatum were dumped with garden wastes at least five years ago, took root and formed a dense colony. Currently, this species should be treated as a casual alien in Lithuania; however, its naturalisation in the future is expected, though its invasion is unlikely.

\section{CONCLUSIONS}

The evaluation of the data on size, density and presumed age of the populations of the recorded new alien plant species revealed that ten species are currently casual in Lithuania. Two alien species $(\mathrm{Co}-$ lutea arborescens and Genista sagittalis) are locally naturalised in the country, because their populations exist already for several decades, plants successfully reproduce and occupy substantial areas of natural or slightly disturbed habitats. Naturalisation of two analysed species in the foreseen future in Lithuania is unlikely (Buxus sempervirens and Euphorbia marginata). Naturalisation of three species (Aruncus dioicus, Sempervivum arachnoideum and Silphium perfoliatum) is possible, whereas naturalisation of five species is expected in the nearest future. All newly recorded alien species, except Erechtites hieraciifolius and possibly Genista sagittalis, have been introduced intentionally and escaped from cultivation.

The analysis of biological properties of the species as well as available information on their invasiveness in the neighbour regions enabled to conclude that invasion of seven species in Lithuania is unlikely. In contrast, the other five species (Clematis vitalba, Colutea arborescens, Erechtites hieraciifolius, Erigeron strigosus, Lathyrus latifolius) have the potential to become invasive in the country. Therefore, the current distribution of these species all over the country should be estimated and urgent measures, when necessary, should be taken to prevent their further spread and minimise possible adverse effects of their invasion on natural and semi-natural ecosystems.
The results of this study showed that despite permanent studies of alien plant species in Lithuania, new species appear in the country regularly because of the increased propagule pressure of cultivated plants, human activities, environmental disturbances, and climate change. Thus, constant surveys of alien plant species play a vital role in the early detection of potentially invasive plant species and to implement urgent measures for their control and eradication, if necessary.

\section{ACKNOWLEDGEMENTS}

This research was mainly supported by the project "Investigations of the Status of Invasive and Alien Species in Lithuania" (Contract No. 05.5.1-APVAV-018-01-0012) co-financed by the European Union Structural Funds according to the 5th Priority of the European Union Funds Investment Operational Program for 2014-2020 "Environment, Sustainable Use of Natural Resources and Adaptation to Climate Change" under the measure "Biodiversity protection” (05.5.1-APVA-V-018).

\section{REFERENCES}

Akeroyd J.R., 1993: Clematis L. - In: Tutin G.T., Burges N.A., Chater A.O., Edmondson J.R., Heywood V.H., Moore D.M., Valentine D.H., Walters S.M., Webb D.A. (eds), Flora Europaea (Second Edition), 1: 266-267. - Cambridge-New York-Melbourne.

APG, 2016: An update of the Angiosperm Phylogeny Group classification for the orders and families of flowering plants. APG IV. - Botanical Journal of the Linnaean Society, 181: 1-20.

Arianoutsou M., Bazo I., Delipetrou P., KokkoRIS Y., 2010: The alien flora of Greece: taxonomy, life traits and habitat preferences. - Biological Invasions, 12(10): 3525-3549.

Aymerich P., SÁez L., 2019: Checklist of the vascular alien flora of Catalonia (north-eastern Iberian Peninsula, Spain). - Mediterranean Botany, 40(2): 215-242. https://doi.org/10.5209/mbot.63608.

Ball P.W., 1968: Lathyrus L. - In: Tutin T.G., HeYwood V.H., Burges N.A., Moore D.M., Valentine D.H., Walters S.M., Webb D.A. (eds), Flora Europaea, 2: 136-143. - Cambridge. 
BARKLey T.M., 1986: Asteraceae. - In: Great Plains Flora Association, Flora of the Great Plains: 839 1021. - Lawrence.

BARKLEY T.M., 2006: Erechtites Rafinesque. - In: Flora of North America north of Mexico. Asteraceae, 20: 163-164. - New York-Oxford.

Berry P.E., Peirson J.A., Steinmann V.W., Morawetz J.J., Rina R., Yang Y., Geltman D., CACHO N.I., 2016: Euphorbia. - In: Flora of North America Editorial Committee: Flora of North America north of Mexico, 12: 237-324. - New York-Oxford.

Browicz K., 1968: Colutea L. - In: Tutin T.G., HeYwood V.H., Burges N.A., Moore D.M., Valentine D.H., Walters S.M., Webb D.A. (eds), Flora Europaea, 2: 107. - Cambridge.

Bungard R.A., Daly G.T., Mcneil D.L., Jones A.V., Morton J.D., 1997: Clematis vitalba in a New Zealand native forest remnant: does seed germination explain distribution? - New Zealand Journal of Botany, 35(4): 525-534.

Carter S., Cullen J., 1997: Euphorbia. - In: Cullen J., Alexander J.C.M., Brickell C.D., EdMondson J.R., Green P.S., Heywood V.H., Brady A., Walters S.M., Yeo P.F. (eds), European Garden Flora, 5: 81-101. - Cambridge.

Celka Z., Szkudlarz P., Shevera M.V., Milicka N., 2017: Morphological variation of Erechtites $h i$ eracifolia (L.) Raf. ex DC. (Asteraceae) achenes in the zone of the species' geographic range expansion, based on the localities from East-Central Europe. - Baltic Forestry, 23(2): 356-363.

Danihelka J., Chrtek J., Kaplan Z., 2012: Checklist of vascular plants of the Czech Republic. - Preslia, 84: 647-811.

Darbyshire S.J., Francis A., Di Tommasi A., ClemENTS D.R., 2012: The biology of Canadian weeds. 150. Erechtites hieraciifolius (L.) Raf. ex DC. Canadian Journal of Plant Science, 92: 729-746.

Decoce G., Bordier D., Wattez J.R., Racinet P., 2004: A practical approach to assess the native status of a rare plant species: the controversy of Buxus sempervirens L. in northern France revisited. - Plant Ecology, 173: 139-151.

Efe A., Özhatay E., Aksoy N., Demir Oral D., 2009: Chamaespartium Adans. (Leguminosae): a new record for the flora of Turkey. - Turkish Journal of Botany, 33: 453-456.
Essl F., Rabitsch W., 2002: Neobiota in Österreich. - Wien.

Frey D., Baltisberger M., Edwards P.J., 2003: Cytology of Erigeron annuus s.l. and its consequences in Europe. - Botanica Helvetica, 113(1): $1-14$.

Fyąkowska K., Adamowski W., 2017: Nowe stanowisko Clematis recta (Ranunculaceae) w Puszczy Białowieskiej (Polska północno-wschodnia). Fragmenta Floristica et Geobotanica Polonica, 24(1): 161-164.

Gederaas L., Moen T.L., SkJelseth S., Larsen L.K. (eds), 2012: Alien species in Norway with the Norwegian Black List 2012. - Trondheim.

Górski P., Czarna A., Tokarska-Guzik B., 2003: Distribution of Erechtites hieracifolia (L.) Raf. ex DC. (Asteraceae) in Poland. - In: ZaJĄC A., Zając M., Zemanek B. (eds), Phytogeographical problems of synanthropic plants: 147-153. - Cracow.

Greuter W., 2006: Compositae (pro parte majore). In: Greuter W., RaAb-Straube E. von (eds), Compositae. Euro+Med Plantbase - the information resource for Euro-Mediterranean plant diversity. - http://ww2.bgbm.org/EuroPlusMed/.

Gudžinskas Z., Petrulaitis L., 2014: Helianthus grosseserratus, a new alien plant species in Lithuania. - Botanica Lithuanica, 20(2): 173176.

Gudžinskas Z., Petrulaitis L., Arlikevičiūté L., 2014: Vaccinium macrocarpon - a new alien plant species in Lithuania. - Botanica Lithuanica, 20(1): 41-45.

Gudžinskas Z., Petrulaitis L., Žalneravičius E., 2017: New woody alien plant species recorded in Lithuania. - Botanica Lithuanica, 23(2): 153168.

Gudžinskas Z., Petrulaitis L., Žalneravičıus E., 2019: Asclepias speciosa (Apocynaceae, Asclepiadoideae): a rare or unrecognized alien species in Europe? - PhytoKeys, 121: 29-41.

Guo W.-Y., van Kleunen M., Pierce S., Dawson W., Essl F., Kreft H., Maurel N., Pergl J., SeeBens H., Weigelt P., PyšEk P., 2019: Domestic gardens play a dominant role in selecting alien species with adaptive strategies that facilitate naturalization. - Global Ecology and Biogeography, 28: 628-639. 
Haeuser E., Dawson W., Thuiller W., Dullinger S., Block S., Bossdorf O., Carboni M., Conti L., Dullinger I., Essl F., Klonner G., Moser D., Münkemüller T., Parepa M., Talluto M. V., Kreft H., Pergl J., Pyšek P., Weigelt P., Winter M., Kühn I., Hermy M., Van der Veken S., Roquet C., van Kleunen M., 2018: The European ornamental garden flora as an invasion debt under climate change. - Journal of Applied Ecology, 55: 2386-2395.

Halliday G., 1976: Erigeron L. - In: Tutin T.G., Heywood V.H., Burges N.A., Moore D.M., VALentine D.H., Walters S.M., Webb D.A. (eds), Flora Europaea, 4: 116-120. - Cambridge-London-New York-Melbourne.

Hartvig P., Leth P., Nielsen H., Plöger E., 1992: Atlas Flora Danica. Taxonliste. - København.

Hulme P.E., 2003: Biological invasions: Winning the science battles but losing the conservation war? Oryx, 37: 178-193.

Hulme P.E., Brundu G., Carboni M., DehnenSchmutz K., Dullinger S., Early R., Essl F., GonzÁlez-Moreno P., Groom Q.J., Kueffer C., Kühn I., Maurel N., Novoa A., Pergl J., Pyšek P., Seebens H., Tanner R., Touza J.M., van Kleunen M., Verbrugge L.N.H., 2018: Integrating invasive species policies across ornamental horticulture supply chains to prevent biological invasions. - Journal of Applied Ecology, 55: 92-98.

Jalas J., Suominen J., Lampinen R., Kurtto A. (eds), 1999: Atlas Florae Europaeae. 12. Resedaceae to Platanaceae. - Helsinki.

JoNSELL L., 2010: Upplands Flora. - Uppsala.

KARLSSON T., 1998: Förteckning över svenska kärlväxter. - Svensk Botanisk Tidskrift, 91: 241560.

Kaźmierczakowa R., Bloch-OrŁowska J., Celka Z., Cwener A., Dajdok Z., Michalska-Hejduk D., PaWlikowski P., Szczę́́niak E., Ziarnek K., 2016: Polska czerwona lista paprotników i roślin kwiatowych. Polish red list of pteridophytes and flowering plants. - Kraków.

Keller R.P., Geist J., Jeschke J.M., Kühn I., 2011: Invasive species in Europe: ecology, status, and policy. - Environmental Sciences Europe, 23: 23. https://doi.org/10.1186/2190-4715-23-23

Khuroo A.A., Rashid I., Reshi Z., Dar G.H., WA-
FAI B.A., 2007: The alien flora of Kashmir Himalaya. Biological Invasions, 9: 269-292. https:// doi.org/10.1007/s10530-006-9032-6

Knees S.G., Maxwell H.S., Hyam R., Rowley G.D., 1995: Crassulaceae. - In: The European Garden Flora, 3: 170-244. - Cambridge.

Kolomiychuk V., Shevera M., Vorobyov E., OrLov O., Pryadko O., 2019: Erechtites hieracifolia (L.) Raf. ex DC. (Asteraceae Bercht. \& P. Presl), new for the Kyiv Polissia alien species. - Visnyk Taras Shevchenko National University of Kyiv. Biologia, 3(79): 37-43.

KowARIK I., 1995: Time lags in biological invasions with regard to the success and failure of alien species. - In: Pyšek P., Prach K., Rejmánek M., WADE M. (eds), Plant Invasions, General Aspects and Special Problems: 15-38. - Amsterdam.

KÜHN I., KLOTZ S., 2006: Urbanization and homogenization. Comparing the floras of urban and rural areas in Germany. - Biological Conservation, 127(3): 292-300.

KukK T., 1999: Eesti taimestik. Vascular Plant Flora of Estonia. - Tartu-Tallinn.

Kurtto A., Lampinen R., JunikKa L., 2004: Atlas Florae Europaeae. 13. Rosaceae (Spiraea to Fragaria, excl. Rubus). - Helsinki.

Laivinș̌ M., Krampis I., Bice M., Knape D., Šulcs V., 2009: Atlas of Latvian Woody Plants. - Rīga.

LARKIN D.J., 2012: Lengths and correlates of lag phases in upper-Midwest plant invasions. - Biological Invasions, 14: 827-838.

MASLO S., ŠARIĆ Š., 2018: Euphorbia marginata (Euphorbiaceae): new alien species in the flora of Bosnia and Herzegovina. - Thaiszia. Journal of Botany, 28(2): 145-149.

Matthews J., Beringen R., Creemers R., Hollander H., van Kessel N., van Kleef H., van de Koppel S., Lemaire A.J.J., Odé B., VAn der Velde G., Verbrugge L.N.H., Leuven R.S.E.W., 2014: Horizon-scanning for new invasive non-native species in the Netherlands. - Nijmegen.

Maxwell B., Lehnhoff E., Rew L., 2009: The rationale for monitoring invasive plant populations as a crucial step for management. - Invasive Plant Science and Management, 2(1): 1-9. https://doi. org/10.1614/IPSM-07-054.1

Medvecká J., Kliment J., Májeková J., Halada L., Zaliberová M., Gojdičová E., Feráková V., Ja- 
ROLÍMEK I., 2012: Inventory of the alien flora of Slovakia. - Preslia, 84: 257-309.

Mito T., Uesugi T., 2004: Invasive alien species in Japan: the status quo and the new regulation for prevention of their adverse effects. - Global Environmental Research, 8: 171-191.

Molnár C., Csathó A.I., Molnár Á.P., Pifkó D., 2019: Amendments to the alien flora of the Republic of Moldova. - Studia Botanica Hungary, 50(1): 225-240. https://doi.org/10.17110/ StudBot.2019.50.1.225

NĀburga I., Evarts-Bunders P., 2019: Status of some escaped ornament perennials in the flora of Latvia. - Botanica, 25(2): 131-144.

NAtKeviČAitė M., 1951: Lietuvos TSR adventyvinè flora. - Biologijos instituto darbai, 1: 44-123.

Navasaitis M., 2008: Dendrologija. - Vilnius.

Nesom G.L., 2006: Erigeron L. - In: Flora of North America Editorial Committee (eds), Flora of North America, 20: 256-348. - New York-Oxford.

OBerdorfer E., 1983: Pflanzensoziologische Exkursionsflora. - Stuttgart.

Otto R., Verloove F., 2019: Erigeron annuus subsp. strigosus (Muhl. ex Willd.) Wagenitz. - In: RAABStraube E. von, Raus Th. (eds), Euro+MedChecklist Notulae, 11. - Willdenowia 49: 427 430. https:// doi.org/10.3372/wi.49.49312

Pashrevich N., 2020: Alien species plant of the information system of Ukraine (Asteraceae, Poaceae, Brassicaceae). - Acta Oecologica Carpatica, 12(1): 13-36.

Pergl J., Sádlo J., Petřík P., Danihelka J., Chrtek J.Jr., Hejda M., Moravcová L., Perglová I., ŠtAJEROVÁ K., PYšEK P., 2016: Dark side of the fence: ornamental plants as a source for spontaneous flora of the Czech Republic. - Preslia, 88: 163-184.

Petřík P., Sádlo J., Hejda M., Štajerová K., PyŠEK P., Pergl J., 2019: Composition patterns of ornamental flora in the Czech Republic. - NeoBiota, 52: 87-109. https://doi.org/10.3897/ neobiota.52.39260

Petrulaitis L., GudŽInSKas Z., 2020: The first records of two alien woody species, Cornus alternifolia and Cornus amomum, in Lithuania. - BioInvasions Records, 9(2): 384-392.

PYŠEK P., Richardson D.M., 2006: The biogeography of naturalization in alien plants. - Journal of Biogeography, 33: 2040-2050.
Pyšek P., Danihelka J., Sádlo J., Chrtek J. Jr., Chytrý M., Jarošík V., Kaplan Z., Krahulec F., Moravcová L., Pergl J., Štajerová K., Tichý L., 2012: Catalogue of alien plants of the Czech Republic (2nd edition): checklist update, taxonomic diversity and invasion patterns. - Preslia, 84: 155-255.

Reaser J.K., Burgiel S.W., Kirkey J., BrantLey K.A., Veatch S.D., Burgos-Rodríguez J., 2020: The early detection of and rapid response (EDRR) to invasive species: a conceptual framework and federal capacities assessment. - Biological Invasions, 22: 1-19. https://doi.org/10.1007/ s10530-019-02156-w

REYNolds S.C.P., 2000: A catalogue of alien plants in Ireland. - Glasnevin.

Seebens H., Essl F., Dawson W., Fuentes N., Moser D., Pergl J., Pyšek P., van Kleunen M., Weber E., Winter M., Blasius B., 2015: Global trade will accelerate plant invasions in emerging economies under climate change. - Global Change Biology, 21: 4128-4140.

Sennikov A.N., Kurtto A., 2019: The taxonomy and invasion status assessment of Erigeron annuus s.l. (Asteraceae) in East Fennoscandia. - Memoranda Societatis Fauna and Flora Fennica, 95: 40-59.

Shrestha U.B., Shrestha B.B., 2019: Climate change amplifies plant invasion hotspots in Nepal. - Diversity and Distributions, 25: 1599-1612.

Stace C., 1997: New Flora of the British Isles (Second Edition). - Cambridge.

Talavera S., 1999: Chamaespartium Adans. - In: Flora Iberica. Leguminosae - Cytiseae, 7(2): 128-133. - Madrid.

TAura L., GudžInSKas Z., 2020: Life stages and demography of invasive shrub Cytisus scoparius (Fabaceae) in Lithuania. - Botanica, 26(1): 1-14.

Theoharides K.A., Dukes J.S., 2007: Plant invasion across space and time: factors affecting nonindigenous species success during four stages of invasion. - New Phytologist, 176: 256-273.

Tokarska-GuZik B., Dajdok Z., ZająC M., Zając A., Urbisz A., Danielewicz W., Holdyński Cz., 2012: Rośliny obcego pochodzenia w Polsce ze szczególnym uwzględnieniem gatunków inwazyjnych. - Warszawa.

TokAryuk A.I., Chorney I.I., Budzhak V.V., 2017: Erechtites hieracifolia (L.) Raf. ex DC. (Aster- 
aceae) in meadow complexes of Pocuttya. - Biological Systems, 9(1): 144-146.

Tretjakov D.I., Dubovik D.I., Orlov A.A., JakushENKO D.N., 2011: Erechtites hieraciifolius (L.) Raf. ex DC. (Asteraceae) in [sic!] the Belarus et the Ukraine. - Botanika (Issledovanija), 40: 138-147.

Turland N.J., Wiersema J.H., Barrie F.R., Greuter W., Hawksworth D.L., Herendeen P.S., Knapp S., Kusber W.-H., Li D.-Z., Marhold K., May T.W., McNeill J., Monro A.M., Prado J., Price M.J., Smith G.F. (eds), 2018: International Code of Nomenclature for algae, fungi, and plants (Shenzhen Code) adopted by the Nineteenth International Botanical Congress Shenzhen, China, July 2017. - Glashütten. https://doi.org/10.12705/ Code. 2018

Tutin T.G., 1968a: Aruncus L. - In: Tutin T.G., Heywood V.H., Burges N.A., Moore D.M., Valentine D.H., Walters S.M., Webb D.A. (eds), Flora Europaea, 2: 6. - Cambridge.

Tutin T.G., 1968b: Chamaespartium Adans. In: Tutin T.G., Heywood V.H., Burges N.A., Moore D.M., Valentine D.H., Walters S.M., Webi D.A. (eds), Flora Europaea, 2: 205. - Cambridge.

Tutin T.G., 1976: Silphium L. - In: Tutin T.G., HeYwood V.H., Burges N.A., Moore D.M., Valentine D.H., Walters S.M., WebB D.A. (eds), Flora Europaea, 4: 142. - Cambridge.

van Kleunnen M., Essl F., Pergl J., Brundu G.,
Carboni M., Dullinger S., Early R., GonzálezMoreno P., Groom Q., Hulme P. E., Kueffer C., Kühn I., Máguas C., Maurel N., Novoa A., Parepa M., Pyšek P., Seebens H., Tanner R., Touza J., Verbrugge L., Weber E., Dawson W., Kreft H., Weigelt P., Winter M., Klonner G., Talluto M.V., Dehnen-Schmutz K., 2018: The changing role of ornamental horticulture in plant invasions. - Biological Reviews, 93: 1421-1437. Wagenitz G., 1965: Compositen (Korbblütler) II. Teil. - In: Wagenitz G. (ed.), Hegi Illustrierte Flora von Mitteleuropa. Zweite auflag, 6(3): 81160 - München.

WebB D.A., 1968: Buxus L. - In: Tutin T.G., Heywood V.H., Burges N.A., Moore D.M., Valentine D.H., Walters S.M., WebB D.A. (eds), Flora Europaea, 2: 243. - Cambridge.

Woch M.W., 2012: New and rare synanthropic plant species of the Polish flora on dormant sedimentation ponds of the Siersza Power Plant. - Fragmenta Floristica et Geobotanica Polonica, 19(1): 29-38.

Zając A., Zając M. (eds), 2001: Atlas rozmieszczenia roślin naczyniowych w Polsce. Distribution Atlas of Vascular Plants in Poland. - Kraków.

Zaniewski P.T., WoŁkowycki D., Szczepkowski A., Otręba A., Zaniewska E., KęBŁowska A., 2020: Patterns of invasion, biology and ecology of Erechtites hieraciifolia in the northern expansion range in Europe (C and NE Poland). - Baltic Forestry, 26(1): BF409. https://doi.org/10.46490/BF409

\section{PIETŲ LIETUVOJE APTIKTOS NAUJOS SVETIMŽEMĖS AUGALŲ RŪŠYS}

\section{Zigmantas Gudžinskas, Laurynas Taura}

\section{Santrauka}

Svetimžemių augalų rūšių skverbimasis ị naujas teritorijas yra vienas iš aiškiausiai pastebimų globalios aplinkos kaitos reiškinių. Jis ypač suintensyvejjo prieš kelis dešimtmečius ir, nepaisant dedamų pastangų pristabdyti svetimžemių rūšiu gausèjimą ir jų daromą neigiamą poveikị, tempai nelètèja. Igyvendinant projektą „Invazinių ir svetimžemių rūšių būklès tyrimai Lietuvoje“, 2020 m. pietineje šalies dalyje,
Alytaus, Druskininkų, Kalvarijos, Lazdijų, Marijampolès, Šalčininkų ir Varènos rajonuose, buvo aptikta anksčiau neužregistruotų svetimžemių rūšių, kurios aprašomos šiame straipsnyje. Taip pat pateikiama informacija apie ankstesniais metais Pietų Lietuvoje aptiktas dvi naujas svetimžemes rūšis. Straipsnyje aprašytos 12 naujų svetimžemių augalų radavietės, populiacijų dydis, dauginimosi ypatybès, aptartos jų 
natūralizacijos galimybès ir prognozuojamas invazyvumas.

Ivertinus surinktus duomenis nustatyta, kad 10 rūšių šiuo metu nèra ịsitvirtinusios, tačiau Colutea arborescens ir Genista sagittalis natūralizavęsi Pietų Lietuvoje. Buxus sempervirens ir Euphorbia marginata natūralizacijos tikimybè Lietuvoje mažai tikètina, Aruncus dioicus, Sempervivum arachnoideum ir Silphium perfoliatum ateityje gali natūralizuotis. Kitų penkių rūšių natūralizacijos tikimybė yra didelè. Visos naujai aptiktos svetimžemès augalų rūšys, išskyrus dvi (Erechtites hieraciifolius ir, tikètina,

\section{Appendix I.}

\section{The list of examined herbarium specimens}

\section{Aruncus dioicus (Walter) Fernald}

Varèna district, Papiškiai, the eastern shore of Savistas Lake, at the edge of the black alder stand on a slope, several clumps; $54.34688^{\circ} \mathrm{N} ; 24.40957^{\circ} \mathrm{E}$; 20 July 2020, leg. Z. Gudžinskas.

Druskininkai district, $1 \mathrm{~km}$ southwest of Mizarai, bank of the Rivulet Bisilnyčia, at the edge of the black alder stand, large clump occupying $6 \mathrm{~m}^{2} ; 54.01723^{\circ} \mathrm{N} ; 23.93108^{\circ} \mathrm{E} ; 23$ July 2020 ; leg. Z. Gudžinskas.

Varena district, $5 \mathrm{~km}$ southeast of Makniūnai, the Makniūnai Forest near Samūniškè village, in the native pine plantation, one large clump occupying $1 \mathrm{~m}^{2} ; 54.20459^{\circ} \mathrm{N} ; 24.13084^{\circ} \mathrm{E} ; 10$ August 2020; leg. Z. Gudžinskas.

Varèna district, Margionys, in the environs of the cemetery, at the edge of the pine forest, clump occupying $2 \mathrm{~m}^{2} ; 53.99787^{\circ} \mathrm{N} ; 24.28320^{\circ} \mathrm{E} ; 17$ August 2020; leg. Z. Gudžinskas.

\section{Buxus sempervirens L.}

Varèna district, $4 \mathrm{~km}$ south of Vydeniai, Dainava village, in a dry abandoned grassland at the edge of the pine forest near the cemetery, two shrubs; $54.149370^{\circ} \mathrm{N} ; 24.707190^{\circ} \mathrm{E}$; 4 September 2020; leg. Z. Gudžinskas and L. Taura.

\section{Clematis recta $\mathrm{L}$.}

Lazdijai district, Veisiejai Regional Park, ca. $4 \mathrm{~km}$ north of Veisiejai, the Babrai Forest, near the
Genista sagittalis) ị Lietuvą buvo įvežtos tikslingai, auginamos želdynuose ir sulaukèjo.

Išnagrinèjus rūšių biologines savybes ir įvertinus informaciją apie tirtų rūšių invazyvumą gretimuose regionuose nustatyta, kad septynių rūšių augalų invazija Lietuvoje mažai tikètina, o penkios rūšys (Clematis vitalba, Colutea arborescens, Erechtites hieraciifolius, Erigeron strigosus, Lathyrus latifolius) gali pradèti sparčiai plisti ir tapti invazinèmis. Dèl to svarbu ịvertinti šių rūšių paplitimą visoje šalyje ir, jeigu reikia, imtis neatidèliotinų priemonių, kad būtụ sustabdytas jų tolesnis plitimas ir sumažinta jų galimo neigiamo poveikio aplinkai ir ekonomikai rizika.

road to Spartai village, at the edge of the forest, in a dry grassland formed on slopes of an old sand-pit; large clump with multiple stems; $54.139411^{\circ} \mathrm{N}$; $23.676092^{\circ}$ E; 22 June 2016; leg. Z. Gudžinskas and L. Taura.

Trakai district, Užutrakis, old manor park, on a dry grassy slope, under the canopy of trees, two individuals with solitary stems; $54.659106^{\circ} \mathrm{N} ; 24.945912^{\circ} \mathrm{E}$; 28 June 2016; leg. Z. Gudžinskas and L. Petrulaitis.

\section{Clematis vitalba L.}

Trakai district, Lentvaris, on the bank of the River Saide, in grey alder woodland and at its edges, a large stand; $54.66011^{\circ} \mathrm{N} ; 25.03344^{\circ} \mathrm{E} ; 22$ June 2020; leg. Z. Gudžinskas and L. Taura.

Trakai district, Lentvaris, on the bank of the River Saide, in grey alder woodland and at its edges, stand occupying ca. $80 \mathrm{~m}^{2}$ and up to $7 \mathrm{~m}$ high in the tree canopy; $54.66011^{\circ} \mathrm{N} ; 25.03340^{\circ} \mathrm{E} ; 16$ August 2020 ; leg. Z. Gudžinskas.

\section{Colutea arborescens L.}

Alytus district, $2 \mathrm{~km}$ east of Ryliškiai, in the environs of Taručionys village, in sparse mature pine woodland, very dense stand occupying ca. 0.5 ha; $54.21026^{\circ} \mathrm{N} ; 24.05116^{\circ} \mathrm{E} ; 30$ July 2020; leg. Z. Gudžinskas and L. Taura.

Erechtites hieraciifolius (L.) Raf. ex DC.

Varena district, the western edge of Margionys village, the Margionys Forest, in sparse pine woodland, on the former timber storage area; $53.99916^{\circ} \mathrm{N}$; 24.27896 E; 17 August 2020; leg. Z. Gudžinskas. 
Erigeron strigosus Muhl. ex Willd.

Lazdijai district, $4 \mathrm{~km}$ northwest of Veisiejai, the Liūnelis Strict Nature Reserve of the Veisiejai Regional Park, in dry grassland, a small group of plants; $54.12962^{\circ} \mathrm{N} ; 23.66163^{\circ} \mathrm{E} ; 12$ July 2019 ; leg. Z. Gudžinskas and L. Taura.

\section{Euphorbia marginata Pursh}

Alytus district, Muiželènai village, at the roadside, on disturbed soil between the road and shrub stand, two individuals; $54.37296^{\circ} \mathrm{N} ; 24.10520^{\circ} \mathrm{E}$; 31 July 2020; leg. L. Taura and Z. Gudžinskas.

Šalčininkai district, $8 \mathrm{~km}$ north of Eišiškès, Dainava village, at the roadside, on disturbed soil, six individuals with ripe fruits; $54.24816^{\circ} \mathrm{N} ; 24.96974^{\circ} \mathrm{E}$; 1 September 2020; leg. L. Taura and Z. Gudžinskas.

\section{Genista sagittalis L.}

Varèna district, 3,5 km northwest of Merkinè, the Laporaisčiai Forest, in mature pine woodland, relatively abundant; $54.17502^{\circ} \mathrm{N} ; 24.23480^{\circ} \mathrm{E} ; 14 \mathrm{Au}-$ gust 2020; leg. Z. Gudžinskas and L. Taura.

\section{Lathyrus latifolius L.}

Alytus district, $1 \mathrm{~km}$ east of Daugai, Sala village, at the edge of the shrub stand by the road, several individuals; $54.35419^{\circ} \mathrm{N} ; 24.35869^{\circ}$ E; 17 July 2020 ; leg. Z. Gudžinskas and L. Taura.
Varèna district, $1 \mathrm{~km}$ northwest of Liškiava, Dzūkija National Park, in an abandoned dry grassland, stand occupying ca. $2 \mathrm{~m}^{2} ; 54.08728^{\circ} \mathrm{N} ; 24.05356^{\circ} \mathrm{E}$; 29 July 2020; leg. Z. Gudžinskas and L. Taura.

Varèna district, Merkine, in a dry grassland on the slope, stand occupying ca. $46 \mathrm{~m}^{2}$ with coverage ca. $30 \% ; 54.16573^{\circ} \mathrm{N} ; 24.19958^{\circ} \mathrm{E} ; 14$ August 2020; leg. Z. Gudžinskas.

Varena district, $3 \mathrm{~km}$ north of Valkininkai, Dargužiai village, at the edge of the shrub stand by the road, a group of plants occupying ca. $1.5 \mathrm{~m}^{2}$; $54.378350^{\circ} \mathrm{N} ; 24.876958^{\circ} \mathrm{E} ; 2$ September 2020; leg. Z. Gudžinskas.

\section{Sempervivum arachnoideum L.}

Lazdijai district, Šventežeris village, on a dry sandy, the slightly eroded slope at the cemetery, a dense patch occupying ca. $2 \mathrm{~m}^{2} ; 54.24090^{\circ} \mathrm{N}$; $23.65269^{\circ}$ E; 13 July 2020 ; leg. Z. Gudžinskas and L. Taura.

\section{Silphium perfoliatum $\mathrm{L}$.}

Varèna district, $1 \mathrm{~km}$ northwest of Liškiava, Dzūkija National Park, in a pith, at the edge of the forest, stand occupying ca. $3 \mathrm{~m}^{2} ; 54.08733^{\circ} \mathrm{N}$; $24.05340^{\circ}$ E; 29 July 2020 ; leg. Z. Gudžinskas and L. Taura. 